NBER WORKING PAPER SERIES

\title{
BANK HEALTH POST-CRISIS
}

Kyriakos T. Chousakos

Gary B. Gorton

Working Paper 23167

http://www.nber.org/papers/w23167

\author{
NATIONAL BUREAU OF ECONOMIC RESEARCH \\ 1050 Massachusetts Avenue \\ Cambridge, MA 02138 \\ February 2017
}

This paper was prepared for the Banque de France Financial Stability Review. We thank Thomas Bonczek, Arun Gupta, Toomas Laarits, and Adriana Robertson for comments and suggestions. The views expressed herein are those of the authors and do not necessarily reflect the views of the National Bureau of Economic Research.

NBER working papers are circulated for discussion and comment purposes. They have not been peer-reviewed or been subject to the review by the NBER Board of Directors that accompanies official NBER publications.

(C) 2017 by Kyriakos T. Chousakos and Gary B. Gorton. All rights reserved. Short sections of text, not to exceed two paragraphs, may be quoted without explicit permission provided that full credit, including $\left({ }^{\circ}\right.$ notice, is given to the source. 
Bank Health Post-Crisis

Kyriakos T. Chousakos and Gary B. Gorton

NBER Working Paper No. 23167

February 2017

JEL No. E32,E44,G01,G2,G21

\section{ABSTRACT}

Economic growth is persistently low following a financial crisis, possibly because of a continuing weal banking system. In a financial crisis bank health is significantly damaged. Post-crisis regulatory changes have aimed at restoring bank health, but measuring bank health by Tobin's Q, we find that the ill health of banks in the recent U.S. financial crisis and the Euro crisis has persisted, especially compared to other crises in advanced economies. The low Q's cannot be explained by the state of the macro-economy. The results seem to suggest that bank regulatory changes may be repressive.

Kyriakos T. Chousakos

Yale School of Management

165 Whitney Ave

New Haven, CT 06511

kyriakos.chousakos@yale.edu

Gary B. Gorton

Yale School of Management

135 Prospect Street

P.O. Box 208200

New Haven, CT 06520-8200

and NBER

Gary.Gorton@yale.edu 


\section{Introduction}

Why does low economic growth persist following a financial crisis? 1 While there are many possible explanations for the persistence of low growth following a financial crisis, one important possibility is that banks do not recover quickly. By definition, a financial crisis, runs on the banking system, is bad for the health of banks. Bank health is clearly important because we know that after a financial crisis unhealthy banks reduce lending. Many studies point to a transmission channel of post-crisis bank distress as causing lower economic growth 2 But, how bad is a crisis for bank health? And, how long are banks ill? We explore these questions across countries and crises using Tobin's Q as a summary measure of bank health. We examine banks' health for five (and ten) years before a financial crisis and five (and ten) years after a financial crisis. In essence, Tobin's Q is a measure of the viability of banks' business models. We find that European and American banks suffered shocks to their health in the financial crises and that this sickness has persisted for five years (and ten years) after the Euro Crisis and the U.S. Financial Crisis, respectively. This pattern of a shock to bank health and the persistence of ill health is not present in other bank crises in advanced economies.

Banks suffer declines in capital during a financial crisis, and after a crisis they must adjust to new bank regulations. After the recent U.S. and Euro financial crises, new international and national bank regulatory reforms have included higher capital requirements, higher liquidity requirements, limitations on leverage ratios, and the introduction of stress tests. In some countries the activities of banks were constrained, e.g., the Volcker Rule. And, in the U.S. the assessment for deposit insurance was changed to be based on total liabilities, regardless of the bank's level of insured deposits. Securitization became moribund following the recent crises, raising banks' funding costs. Further, in the aftermath of the recent crisis banks have faced billions of dollars of fines with legal uncertainty still remaining. And, banks have struggled in a low interest rate and low growth environment.

The recent crises in the U.S. and Europe, significantly worse in terms of output declines compared to other modern crises in advanced economies, show persistently ill banks compared to the other crises, as measured by Tobin's Q. We also find that the dispersion of bank Q-ratios has declined post-crisis. Low Q banks may have failed, but low Q dispersion seems hard to explain as being due to capital leaving banking (for low Q banks), just when capital ratios have been increased. Another explanation is that low, bunched,

\footnotetext{
${ }^{1}$ Low economic growth following financial crises is documented, for example, by Cerra and Saxena (2008) and Reinhart and Rogoff (2014).

${ }^{2}$ See, for example, Gibson (1995), Rosengren and Peek (2000), Calomiris and Mason (2003), Dell'ariccia et al. (2008), Ivashina and Scharfstein (2010), Mladjan (2012), Iyer et al. (2014), Chodorow-Reich (2014), Frydman et al. (2015), Lee and Mezzanotti (2014), Carlson and Rose (2015). These papers show that post-crisis declines in lending are significantly due to bank loan supply, rather than to a low demand for loans, which may also be present.
} 
Q-ratios are due to regulation making all banks essentially the same and inefficient. This persistence suggests that traditional bank business models may no longer be viable. It also suggests that new regulations have not served to revitalize banking, but may have had the opposite effect. As measured by Tobin's Q, the future of U.S. and European banks is not bright.

This paper is related to Sarin and Summers (2016) and Calomiris and Nissim (2014). Sarin and Summers (2016) examine a variety of measures of bank riskiness pre- and post-crisis, e.g., stock price volatility, credit default swaps, option-implied volatility, and find that banks are riskier post-crisis than before the crisis. They write that: ". . . our findings are most consistent with a dramatic decline in franchise [charter] value of major financial institutions, caused at least in part by new regulations" (abstract). Our findings are consistent with this. We, however, focus on a different issue, namely, the pattern of bank health pre- and post-crisis in different crises across countries. Calomiris and Nissim (2014) study the cross section of U.S. banks' Tobin's Q's pre- and post- the recent U.S. financial crisis, relating their panel to measures of banks' activities. They find that low Q's indicate (in cross-section) that banks' investments in intangibles (e.g., human capital, information technology) are expected to generate negative economic profits in the future. This conclusion is also consistent with what we find, although we do not focus on a cross section of banks but on a cross section of countries.

We proceed as follows. In Section 1 we discuss the use and role of Tobin's Q in studying banking. We also discuss our data. Section 2 contains the main results. Final thoughts are contained in Section 3

\section{$1 \quad$ Measuring Bank Health}

\subsection{Tobin's Q}

While Tobin's Q is widely used in economics, it plays a particular role in the case of banks because of bank "charter value" 3 In general, charter value derives from rents or quasi-rents on assets-in-place and future investment opportunities. Banks make loans, which involves banks in the production of valuable private information about borrowers. This information is valuable for future loans and the associated bank relationship makes it hard for borrowers to switch banks. See Slovin et al. (1993) and Darmouni (2016). For a bank, rents or quasi-rents accruing from this information production are an intangible asset which the bank loses if it fails. These informational quasi-rents are the bank's private "charter value". In addition, charter

\footnotetext{
${ }^{3}$ This is sometimes called "franchise value". See Marcus (1984). High bank charter value (Q greater than one) is viewed as providing an incentive for banks to avoid risk, for fear of losing this intangible asset. There is an empirical literature documenting the decline in U.S. bank charter values in the 1980s. See Keeley (1990), Gorton and Rosen (1995) and Demsetz et al. (1996).
} 
value may derive from regulatory barriers to entry or from oligopolistic behavior that limits entry 4 Since banks uniquely produce short-term debt bearing a convenience yield, limitations on entry would also create charter value due to this cheaper source of funding. In oligopolistic industries like banking, the Q's may normally be above one, and can stay that way if there are barriers to entry.

We use a simple measure of Tobin's Q:

$$
\text { Q-ratio }=\frac{\text { market capitalization }}{\text { book value of equity }}
$$

While there are more complicated ways of constructing Tobin's Q, these other methods result in measures that are very highly correlated with the simple measure. See Chung and Pruitt (1994).

We construct indices of $\mathrm{Q}$ for countries experiencing different crises as follows. We first construct an annual $\mathrm{Q}$ for each bank in a country. These are then valued-weighted (by total assets) to get a country Q index. For all countries involved in a crisis, e.g., the Euro Crisis, we weight countries by real GDP, to obtain a $\mathrm{Q}$ index for that crisis or set of crises.

\subsection{Data}

Our data are from WorldScope and the World Development Indicators of the World Bank. The categories of financial institutions used in the analysis are commercial banks, including multi-bank holding companies and single bank holding companies, and savings \& loan holdings companies 5 . We also look separately at (what were) the U.S. investment banks. The data are annual and span 1980 until 2015. We merge the real GDP data with the Credit-to-the-Private-Sector data, from the World Development Indicators. All variables are winsorized at the $1 \%$ level. Table 1 summarizes the data, grouping data into all U.S. banks, European banks, and the banks in the other countries that experienced financial crises. This last group will be called "the benchmark".

The variable "Short Yield" is a measure of the yield on short maturity government debt. It is apparent from the table that even winsorizing at $1 \%$, the data appear to be somewhat noisy. This is perhaps due to differences in accounting procedures.

For the benchmark we use the dates of financial crises (other than the recent crises in the U.S. and

\footnotetext{
${ }^{4}$ On oligopolistic bank behavior see Gorton and He (2008).

${ }^{5}$ We exclude investment companies, commercial finance companies, insurance companies, land and real estate companies, personal loan companies, real estate investment trusts and business trusts, rental and leasing, savings and loans holding companies, and securities brokerage firms. Results do not change if the savings \& loan holding companies are excluded.
} 
Table 1: The table summarizes the mean, standard deviation, min, and max of asset weighted average $Q$-ratio, Assets, $\Delta($ Assets $)$, and $\sigma\left(Q_{i}\right)$ for the financial sector of each country in our sample, and $r G D P$, $\Delta r G D P, C r e d i t$, and $\Delta C r e d i t$ for the economies of the countries in our sample. All variables are winsorized at the $1 \%$ level.

\begin{tabular}{lccccc}
\hline & Count & Mean & St.Dev & Min & Max \\
\hline$Q w(U S)$ & 11 & 1.331 & 0.615 & 0.607 & 2.247 \\
$Q w(E U)$ & 143 & 0.975 & 0.968 & 0.003 & 5.995 \\
$Q w(A D V)$ & 91 & 0.867 & 0.715 & 0.045 & 4.333 \\
Assets $(U S$-in bn. $)$ & 11 & 9903.985 & 2558.256 & 5545.909 & 12687.262 \\
Assets $(E U$-in bn. $)$ & 148 & 920.024 & 375.217 & 407.648 & 1725.432 \\
Assets $(A D V$-in bn. $)$ & 94 & 667.021 & 706.578 & 19.024 & 2514.259 \\
$\Delta$ Assets $(U S)$ & 10 & 0.086 & 0.119 & -0.122 & 0.256 \\
$\Delta$ Assets $(E U)$ & 132 & 0.093 & 0.373 & -0.882 & 1.625 \\
$\Delta$ Assets $($ ADV $)$ & 85 & 0.104 & 0.245 & -0.506 & 1.394 \\
$r G D P($ in bn. $)$ & 865 & 919.589 & 2050.115 & 6.628 & 16800 \\
$\Delta r G D P$ & 835 & 0.070 & 0.122 & -0.620 & 0.481 \\
Credit & 926 & 80.208 & 47.823 & 0.186 & 312.154 \\
$\Delta$ Credit & 892 & 0.344 & 9.350 & -0.671 & 279.229 \\
Short $Y$ ield & 599 & 11.918 & 35.481 & 0.001 & 816.100 \\
$\sigma(Q-U S)$ & 11 & 0.550 & 0.125 & 0.390 & 0.733 \\
$\sigma(Q-E U)$ & 137 & 0.586 & 0.721 & 0 & 4.734 \\
$\sigma(Q-A D V)$ & 89 & 0.877 & 0.925 & 0.005 & 3.656 \\
No. of Banks (US) & 11 & 795.364 & 90.699 & 641 & 924 \\
No. of Banks (EU) & 148 & 10.257 & 10.963 & 1 & 44 \\
No. of Banks (ADV) & 94 & 36.734 & 56.394 & 1 & 215 \\
\hline
\end{tabular}

Europe) in other advanced countries are from Kaminsky and Reinhart (1999) and Caprio et al. (2005). From these sources we calculate a benchmark for banks' Q's, as described above, before and after financial crises other than the U.S. crisis of 2007-2008 and the Euro Crisis. The benchmark includes the following crises: Australia (1989), Canada (1983), Denmark (1987), France (1994), Germany (1977), Greece (1991), Iceland (1985), Italy (1990), New Zealand (1987), United Kingdom (1974, 1999, 1995), and the United States (1984). Arguably, not all of these crises were systemic, and it seems clear that the Crisis of 2007-2008 and the Euro Crisis were the worse than sample, so the benchmark seems to be with respect to less significant crises. Still, our view is that it is useful for comparison purposes. Keep in mind that Kaminsky and Reinhart (1999) and Caprio et al. (2005) define these events as systemic banking crises.

\section{Post-Crisis Bank Health: Results}

In this section we look at the evolution of bank health around financial crises.

Table 2 shows mean values for Tobin's Q, Total Assets, the cross-sectional dispersion of Q-ratios, and macroeconomic variables over the course of five years prior to and five years after a financial crisis for four sets of banks: all U.S. commercial banks and the U.S. investment banks in the recent U.S. financial crisis, European banks during the Euro Crisis of 2008, and banks in advanced economies that experienced financial crises, discussed above. Tobin's Q-ratios, the number of financial institutions, and change in real GDP and Credit are, on average, lower post-crisis in the U.S. and in the E.U. banks. However, we observe no significant 
differences in the Q-ratios of commercial banks in advanced economies' crises. Note that the policy rate, represented by "Short Yield" is lower post-crisis in all cases, but it is significantly different only in the cases of EU banks and the banks in the benchmark, but not for the U.S. banks.

Table 2 also shows that Tobin's Q was above one prior to the crises in the U.S. and Europe and then fell below one, with the change being statistically significant ${ }^{6}$ In contrast, in the other financial crises, Tobin's Q was just below one in the five years prior to the crises (on average) and is about the same in the five years afterward. Also, real GDP dropped significantly in the U.S. but not in Europe or the other crises.

Figure $1 \mathrm{a}$ shows the evolution of Q-ratio indices for the above mentioned different sets of banks. Figure 1a shows that prior to the U.S. financial crisis and the Euro crisis, banks were healthy with high Tobin's Q's, consistent with high charter value. The Q's plummet during the respective crises and do not recover during the subsequent five years. On the other hand, the average $\mathrm{Q}$ for the banks in countries involved in the benchmark crises show a low Q prior to the crisis, on average, and after the crisis; the Q for this group does not move. It is flat. The figure is substantially the same if we look at the median Q instead of the average Q.

We interpret the high Q's for American and European banks prior to the crisis as evidence of oligopolistic banking systems, systems dominated by a few large banks. In addition, charter value could reflect implicit too-big-to-fail insurance. In any case, in the crises and their aftermaths, this charter value is significantly destroyed, resulting in Q ratios going well below one. And this persists.

Figure $1 \mathrm{~b}$ looks at the Q's for only the U.S. banks that were at the center of the financial crisis, the investment banks. ${ }^{7}$ These firms show a very high charter value prior to the crisis and a huge drop during the crisis. These are the banks for which the Volcker Rule is binding. And this is the set of banks that face the most legal action.

Figure 2 shows the same figures as above but over a decade pre- and post-crisis. Over a ten year period some data are lost so coverage of banks is not as complete as over the five year horizon. Nevertheless, the figures show that the ill health of U.S. and European banks persists beyond five years. This is consistent with Cerra and Saxena 2008) who document output losses from financial crises persisting even at a ten-year horizon. Reinhart and Rogoff (2014), in a study of 100 crisis episodes, find that it takes about eight years to reach the pre-crisis level of income.

\footnotetext{
${ }^{6}$ This is consistent with the findings of Calomiris and Nissim $(2014)$ for the U.S..

${ }^{7}$ These banks are excluded from "all U.S. commercial banks" prior to 2009. The investment banks became commercial banks at the end of 2008 and subsequently are included in "all U.S. commercial banks".
} 
Table 2: Summary statistics (t-statistics of the difference of means). The table summarizes the mean values of asset weighted average $Q$-ratio, Assets, $\Delta$ (Assets), and $\sigma\left(Q_{i}\right)$ for (i) US banks (all) prior to vs. after the 2007 crisis, (iii) EU banks (all) prior to vs. after the 2008 crisis, (ii) specific US banks (Bank of America, Citigroup, Goldman Sachs, JP Morgan, Morgan Stanley, and Wells Fargo) prior to vs. after the 2007 crisis, and (iv) Advanced countries' banks prior to and after major financial crises. The third column reports the difference in means and the $t$-statistic of the difference.

(a) US Banks (All)

\begin{tabular}{|c|c|c|c|}
\hline & Prior & Post & Mean Diff. \\
\hline$Q w$ & 1.947 & 0.817 & $\begin{array}{c}1.131^{* * *} \\
(10.31)\end{array}$ \\
\hline Assets (in bn.) & 7556.335 & 11860.360 & $\begin{array}{c}-4304.026^{* * *} \\
(-5.52)\end{array}$ \\
\hline$\Delta$ Assets & 0.161 & 0.036 & $\begin{array}{l}0.124 \\
(1.80)\end{array}$ \\
\hline$r G D P($ in bn. $)$ & 12344.540 & 15059.200 & $\begin{array}{c}-2714.660^{* *} \\
(-4.78)\end{array}$ \\
\hline$\triangle r G D P$ & 0.055 & 0.027 & $\begin{array}{c}0.028^{+} \\
(2.14)\end{array}$ \\
\hline Credit & 181.549 & 188.431 & $\begin{array}{l}-6.882 \\
(-0.96)\end{array}$ \\
\hline$\Delta C r e d i t$ & 0.031 & -0.015 & $\begin{array}{l}0.047 \\
(1.54)\end{array}$ \\
\hline Short Yield & 2.638 & 0.895 & $\begin{array}{l}1.743 \\
(1.55)\end{array}$ \\
\hline$\sigma(Q)$ & 0.664 & 0.455 & $\begin{array}{c}0.209^{* * *} \\
(5.46)\end{array}$ \\
\hline No. of Banks & 830.200 & 766.333 & $\begin{array}{c}63.867 \\
(1.19)\end{array}$ \\
\hline
\end{tabular}

$+p<0.10,{ }^{*} p<0.05,{ }^{* *} p<0.01,{ }^{* * *} p<0.001$

(c) EU Banks

\begin{tabular}{|c|c|c|c|}
\hline & Prior & Post & Mean Diff. \\
\hline$Q w$ & 1.340 & 0.662 & $\begin{array}{c}0.679^{* * *} \\
(4.45)\end{array}$ \\
\hline Assets (in bn.) & 652.432 & 1147.478 & $\begin{array}{c}-495.046^{* * *} \\
(-10.61)\end{array}$ \\
\hline$\Delta$ Assets & 0.279 & -0.036 & $\begin{array}{c}0.316^{* * *} \\
(5.24)\end{array}$ \\
\hline$r G D P($ in bn. $)$ & 582.430 & 744.729 & $\begin{array}{c}-162.299 \\
(-1.32)\end{array}$ \\
\hline$\Delta r G D P$ & 0.140 & 0.001 & $\begin{array}{c}0.139^{* * *} \\
(10.42)\end{array}$ \\
\hline Credit & 95.328 & 112.516 & $\begin{array}{c}-17.188^{* *} \\
(-2.80)\end{array}$ \\
\hline$\Delta$ Credit & 4.168 & 0.001 & $\begin{array}{c}4.166 \\
(1.10)\end{array}$ \\
\hline Short Yield & 2.907 & 1.834 & $\begin{array}{c}1.073^{* *} \\
(2.82)\end{array}$ \\
\hline$\sigma(Q)$ & 0.669 & 0.521 & $\begin{array}{l}0.147 \\
(1.19)\end{array}$ \\
\hline No. of Banks & 10.824 & 9.775 & $\begin{array}{l}1.049 \\
(0.58)\end{array}$ \\
\hline
\end{tabular}

t-statistics in parentheses

$+p<0.10,{ }^{*} p<0.05,{ }^{* *} p<0.01,{ }^{* * *} p<0.001$ (b) US Banks (Specific)

\begin{tabular}{|c|c|c|c|}
\hline & Prior & Post & Mean Diff. \\
\hline$Q w$ & 1.999 & 0.819 & $\begin{array}{c}1.180^{* * *} \\
(8.02)\end{array}$ \\
\hline Assets (in bn.) & 3969.717 & 7249.063 & $\begin{array}{c}-3279.346^{* * *} \\
(-6.88)\end{array}$ \\
\hline$\Delta$ Assets & 0.163 & 0.074 & $\begin{array}{l}0.089 \\
(1.43)\end{array}$ \\
\hline$r G D P($ in bn. $)$ & 12344.540 & 15059.200 & $\begin{array}{c}-2714.660^{* *} \\
(-4.78)\end{array}$ \\
\hline$\Delta r G D P$ & 0.055 & 0.027 & $\begin{array}{c}0.028^{+} \\
(2.14)\end{array}$ \\
\hline Credit & 181.549 & 188.431 & $\begin{array}{l}-6.882 \\
(-0.96)\end{array}$ \\
\hline$\Delta C r e d i t$ & 0.031 & -0.015 & $\begin{array}{l}0.047 \\
(1.54)\end{array}$ \\
\hline Short Yield & 2.638 & 0.895 & $\begin{array}{l}1.743 \\
(1.55)\end{array}$ \\
\hline$\sigma(Q)$ & 0.553 & 0.345 & $\begin{array}{c}0.209^{* * *} \\
(5.73)\end{array}$ \\
\hline No. of Banks & 4 & 4 & 0 \\
\hline
\end{tabular}

t-statistics in parentheses

$+p<0.10,{ }^{*} p<0.05,{ }^{* *} p<0.01,{ }^{* * *} p<0.001$

(d) Advanced Banks

\begin{tabular}{|c|c|c|c|}
\hline & Prior & Post & Mean Diff. \\
\hline$Q w$ & 0.901 & 0.843 & $\begin{array}{l}0.058 \\
(0.38)\end{array}$ \\
\hline Assets (in bn.) & 579.858 & 737.423 & $\begin{array}{c}-157.565 \\
(-1.08)\end{array}$ \\
\hline$\Delta$ Assets & 0.186 & 0.052 & $\begin{array}{c}0.134^{*} \\
(2.53)\end{array}$ \\
\hline$r G D P($ in bn. $)$ & 702.098 & 1041.596 & $\begin{array}{c}-339.498 \\
(-1.30)\end{array}$ \\
\hline$\Delta r G D P$ & 0.105 & 0.064 & $\begin{array}{c}0.041^{+} \\
(1.82)\end{array}$ \\
\hline Credit & 58.546 & 69.638 & $\begin{array}{c}-11.092^{*} \\
(-2.01)\end{array}$ \\
\hline$\Delta$ Credit & 0.060 & 0.037 & $\begin{array}{l}0.023 \\
(0.61)\end{array}$ \\
\hline Short Yield & 13.503 & 10.003 & $\begin{array}{c}3.500^{* * *} \\
(3.55)\end{array}$ \\
\hline$\sigma(Q)$ & 0.892 & 0.867 & $\begin{array}{l}0.025 \\
(0.13)\end{array}$ \\
\hline No. of Banks & 33.381 & 39.442 & $\begin{array}{l}-6.061 \\
(-0.52) \\
\end{array}$ \\
\hline
\end{tabular}

$+p<0.10,{ }^{*} p<0.05,{ }^{* *} p<0.01,{ }^{* * *} p<0.001$ 
Figure 1: Average Q-ratios (Q-ratios weighted by total assets on a country-year basis and country real GDP on an annual basis - five years prior and after the crisis). In figure (a) the U.S., 2007 Crisis line is the average Q-ratio for U.S. banks five years prior and after the 2007 Crisis In figure (b) the U.S., 2007 Crisis line is the average Q-ratio for specific U.S. banks (Bank of America, Citigroup, Goldman Sachs, JP Morgan, Morgan Stanley, and Wells Fargo) five years prior and after the 2007 Crisis. The Advanced, Crises line is the average Q-ratio five years prior and after the following crises: Australia (1989), Canada (1983), Denmark (1987), France (1994), Germany (1977), Greece (1991), Iceland (1985), and Italy (1990), and New Zealand (1987), United Kingdom (1974, 1991, 1995), and United States (1984). The Euro, 2008 Crisis line is the average Q-ratio five years prior and after the following 2008 crises: Austria, Belgium, Denmark, France, Greece, Hungary, Ireland, Italy, Latvia, Luxembourg, Portugal, Slovenia, Spain, Netherlands, and Sweden.

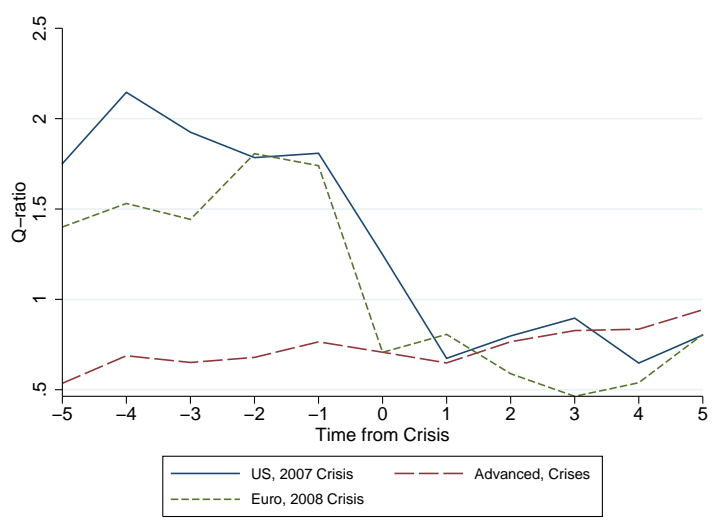

(a) US banks (All)

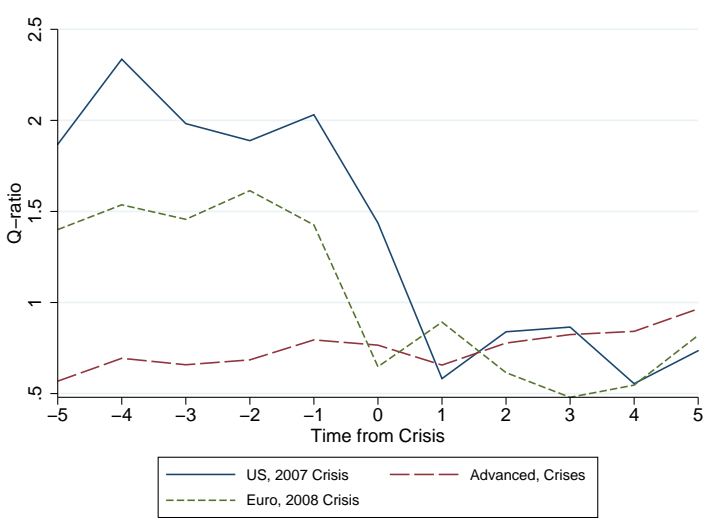

(b) US banks (Specific)

Figure 2: Average Q-ratios (Q-ratios weighted by total assets on a country-year basis and country real GDP on an annual basis - ten years prior and after the crisis). In figure (a) the U.S., 2007 Crisis line is the average Q-ratio for U.S. banks ten years prior and after the 2007 Crisis In figure (b) the U.S., 2007 Crisis line is the average Q-ratio for specific U.S. banks (Bank of America, Citigroup, Goldman Sachs, JP Morgan, Morgan Stanley, and Wells Fargo) ten years prior and after the 2007 Crisis. The Advanced, Crises line is the average Q-ratio ten years prior and after the following crises: Australia (1989), Canada (1983), Denmark (1987), France (1994), Germany (1977), Greece (1991), Iceland (1985), and Italy (1990), and New Zealand (1987), United Kingdom (1974, 1991, 1995), and United States (1984). The Euro, 2008 Crisis line is the average Q-ratio ten years prior and after the following 2008 crises: Austria, Belgium, Denmark, France, Greece, Hungary, Ireland, Italy, Latvia, Luxembourg, Portugal, Slovenia, Spain, Netherlands, and Sweden.

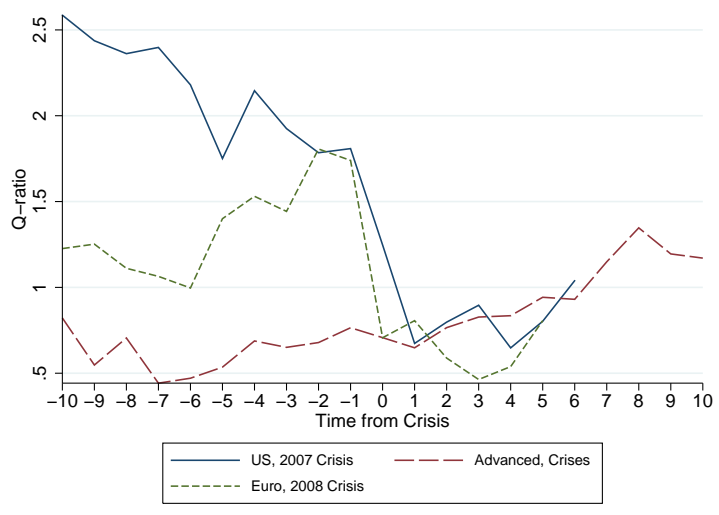

(a) US banks (All)

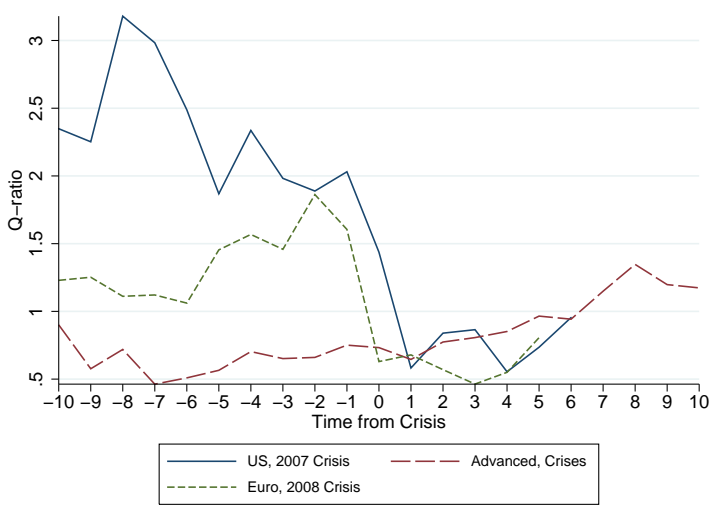

(b) US banks (Specific) 
Table 3: Difference-in-differences regression over the course of a crisis (five years prior and after the beginning of a financial crisis). The table summarizes the effect of the 2007 US financial crisis and 2008 Euro financial crisis on asset weighted average Q-ratios of the financial sector of each country. The panel of countries in the regressions includes all countries in the sample. All regression specifications take into account country and year fixed effects, and standard errors are clustered by country. The specification is: $\log (Q w)_{n, t}=\alpha_{n}+a_{t}+$ $\beta \mathbb{1}(U S \& E U \text { Banks })_{n, t}+\gamma \mathbb{1}(\text { Post Crisis })_{n, t}+\delta \mathbb{1}(U S \& E U \text { Banks })_{n, t} \times \mathbb{1}(\text { Post Crisis })_{n, t}+\zeta^{\prime} X_{n, t}+\epsilon_{n, t}$, where $X_{n, t}=\left(\log (r G D P)_{t}, \Delta \log (r G D P)_{t}, \log (C r e d i t)_{t}, \Delta \log (C r e d i t)_{t}, \log (Q w)_{t-1}\right)^{\prime}$

\begin{tabular}{|c|c|c|c|c|c|}
\hline & $\begin{array}{c}(1) \\
\log (Q w)_{t} \\
\end{array}$ & $\begin{array}{c}(2) \\
\log (Q w)_{t}\end{array}$ & $\begin{array}{c}(3) \\
\log (Q w)_{t}\end{array}$ & $\begin{array}{c}(4) \\
\Delta \log (Q w)_{t}\end{array}$ & $\begin{array}{c}(5) \\
\Delta \log (Q w)_{t}\end{array}$ \\
\hline $\mathbb{1}(U S \& E U \text { Banks })_{t}$ & $\begin{array}{c}1.232^{* *} \\
(3.33)\end{array}$ & $\begin{array}{c}2.047^{+} \\
(1.82)\end{array}$ & $\begin{array}{c}0.000 \\
(.)\end{array}$ & $\begin{array}{c}0.823^{* * *} \\
(11.94)\end{array}$ & $\begin{array}{c}1.188^{* * *} \\
(4.99)\end{array}$ \\
\hline $\mathbb{1}(\text { Post Crisis })_{t}$ & $\begin{array}{l}-0.300 \\
(-1.39)\end{array}$ & $\begin{array}{l}-0.282 \\
(-1.37)\end{array}$ & $\begin{array}{l}-0.108 \\
(-0.56)\end{array}$ & $\begin{array}{l}-0.219 \\
(-1.49)\end{array}$ & $\begin{array}{l}-0.208 \\
(-1.30)\end{array}$ \\
\hline $\mathbb{1}(\text { US \& EU Banks })_{t} \times \mathbb{1}(\text { Post Crisis })_{t}$ & $\begin{array}{c}-0.529^{* *} \\
(-3.68)\end{array}$ & $\begin{array}{c}-0.594^{* * *} \\
(-4.41)\end{array}$ & $\begin{array}{c}-0.615^{* *} \\
(-3.29)\end{array}$ & $\begin{array}{c}-0.301^{*} \\
(-2.51)\end{array}$ & $\begin{array}{c}-0.383^{* *} \\
(-3.35)\end{array}$ \\
\hline $\log (r G D P)_{t}$ & & $\begin{array}{l}-0.351 \\
(-0.69)\end{array}$ & $\begin{array}{c}-0.895^{+} \\
(-2.15)\end{array}$ & & \\
\hline $\log (\text { Credit })_{t}$ & & $\begin{array}{l}-0.115 \\
(-0.34)\end{array}$ & $\begin{array}{l}0.286 \\
(1.43)\end{array}$ & & \\
\hline $\log (\text { ShortYield })_{t}$ & & & $\begin{array}{l}-0.053 \\
(-0.39)\end{array}$ & & \\
\hline$\Delta \log (r G D P)_{t}$ & & & & $\begin{array}{c}1.062^{+} \\
(1.80)\end{array}$ & $\begin{array}{l}0.632 \\
(0.88)\end{array}$ \\
\hline$\Delta \log (\text { Credit })_{t}$ & & & & $\begin{array}{c}-1.295^{* * *} \\
(-4.77)\end{array}$ & $\begin{array}{c}-0.979^{* * *} \\
(-4.71)\end{array}$ \\
\hline $\log (Q w)_{t-1}$ & & & & $\begin{array}{c}-0.398^{* * *} \\
(-5.59)\end{array}$ & $\begin{array}{c}-0.437^{*} \\
(-2.95)\end{array}$ \\
\hline$\Delta \log (\text { ShortYield })_{t}$ & & & & & $\begin{array}{l}-0.092 \\
(-1.30)\end{array}$ \\
\hline Constant & $\begin{array}{c}-1.044^{* * *} \\
(-7.38)\end{array}$ & $\begin{array}{l}1.124 \\
(0.41)\end{array}$ & $\begin{array}{l}2.647 \\
(1.09)\end{array}$ & $\begin{array}{c}21.366^{+} \\
(1.74)\end{array}$ & $\begin{array}{l}12.527 \\
(0.84)\end{array}$ \\
\hline $\mathrm{N}$ & 245 & 244 & 150 & 220 & 133 \\
\hline$R^{2}$ & 0.51 & 0.51 & 0.58 & 0.54 & 0.61 \\
\hline FE (Year) & YES & YES & YES & YES & YES \\
\hline FE (Plan) & YES & YES & YES & YES & YES \\
\hline
\end{tabular}

Table 3 confirms that the difference between the U.S. Crisis and the Euro Crisis and the benchmark is indeed significant. In a difference-in-differences context, a dummy variable for U.S. and EU banks interacted with a dummy for the post-crisis period is highly significant. The table highlights another point, namely that the level and change in Q indices are not associated with measures of the macro-economy, as measured by real GDP or credit-to-the-private sector. This is surprising because we would expect these variables to be significant if low bank Q's were due to the continuing recession (real GDP) or the credit boom prior to the crisis and the subsequent delevering in the economy. The regression also includes a measure of a short interest rate for each country (short yield) intended to capture the effects of the zero lower bound in recent crises. this too is not significant $8^{8}$ But, neither the level nor the change in this variable are significant. Thus

\footnotetext{
${ }^{8}$ These data are from Global Financial Data. The data are not available for our full sample of countries. Excluding the short yield, however, does not alter the results.
} 
the table suggests the presence of other factors explaining the low Q's. We further look into the relationship between Q-ratios and real GDP and Credit in Figure 3 We find that macroeconomic measures have little or no explanatory power over Tobin's Q measure.

Figure 3: Explanatory/predictive regression over the course of a crisis (five years prior and after the beginning of a financial crisis - country/crisis level). Figures (a) through (d) summarize the predictive power of changes in the real GDP, credit to private sector, and their first year lags on the change in Q-ratios. All regressions are performed at the country level (countries with multiple crises treated as separate time series) and standard errors are corrected using Newey-West (1987) with one lag. The regression specification is: $\Delta Q w_{n, t}=\alpha_{n}+a_{t}+\beta^{\prime} X_{n, t}+\epsilon+n, t$, where $X_{n, t}=\left(\Delta r G D P_{n, t}, \Delta r G D P_{n, t-1}, \Delta \text { Credit }_{t}, \Delta \text { Credit }_{t-1}\right)^{\prime}$

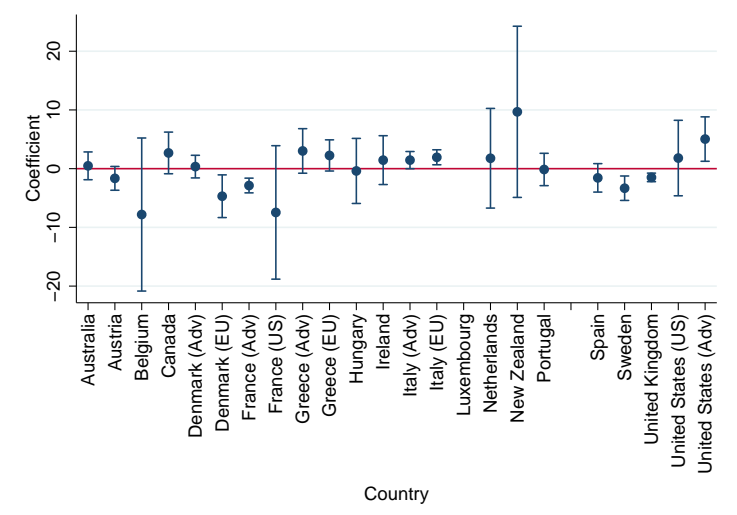

(a) $\Delta$ real GDPt

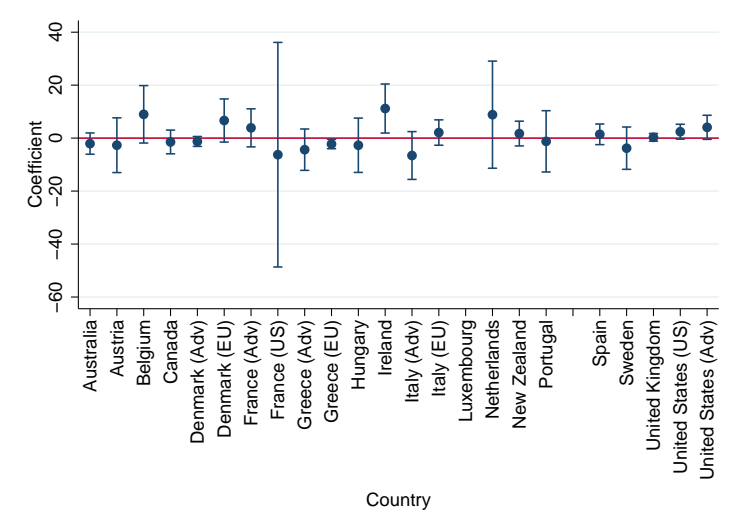

(c) $\Delta$ Credit $_{t}$

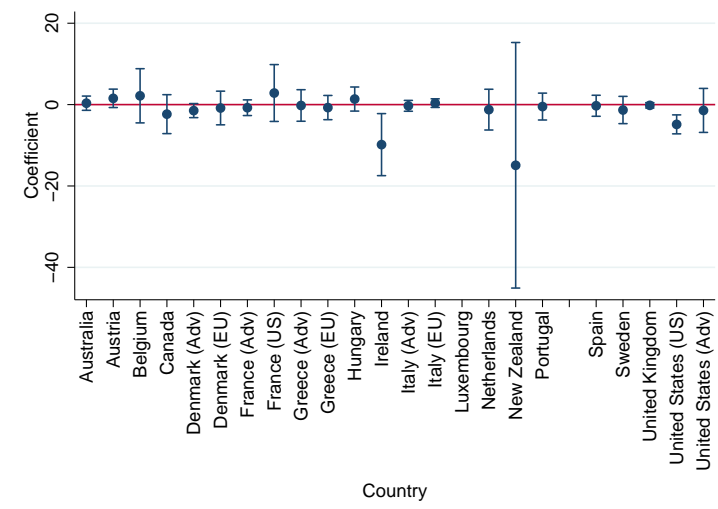

(b) $\Delta$ real $G D P_{t-1}$

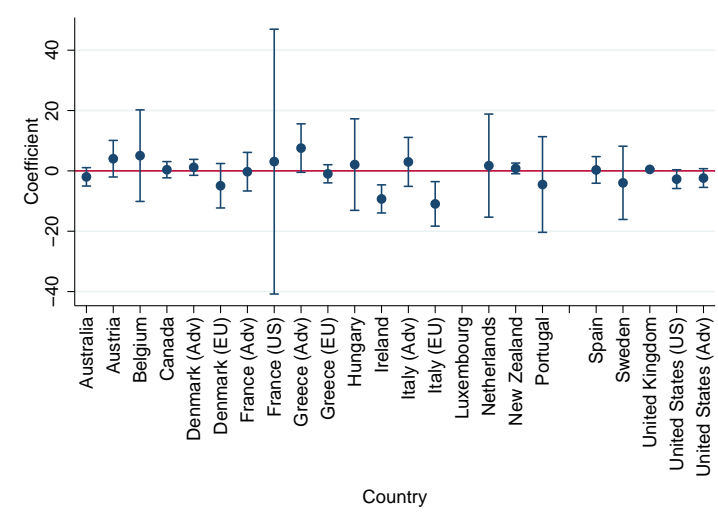

(d) $\Delta$ Credit $_{t-1}$

\subsection{Bank Growth}

We mentioned above the large literature that documents a decline in the supply of loans by banks following a financial crisis. If banks are seriously harmed in a crisis, and quite ill afterward, we should see a decline in loan growth. Our data are not fine enough to examine loans specifically, but we can examine the growth of cash holdings and cash holdings as a percentage of total assets. Higher cash holdings and higher 
cash-to-assets ratios imply lower loan growth since the bank holds on to its cash. In Figure 4 we look at the same three categories of crises as above. In Figure 4a, the cumulative growth of cash holdings starting five years before the crisis (normalized to one in the beginning of the crisis) is significantly higher for banks that experienced the U.S. financial crisis or the Euro crisis compared to the benchmark. Figure 4b shows that the (old) U.S. investment banks perform similarly in terms of cash growth. The patterns in Figure 4 are consistent with low Q's and ill health.

Figure 4: Total cumulative cash growth (five years prior and after the crisis). In figure (a) the U.S., 2007 Crisis line is the total cumulative cash growth for U.S. banks five years prior and after the 2007 Crisis In figure (b) the U.S., 2007 Crisis line is the total cumulative cash growth for specific U.S. banks (Bank of America, Citigroup, Goldman Sachs, JP Morgan, Morgan Stanley, and Wells Fargo) five years prior and after the 2007 Crisis. The Advanced, Crises line is the average cumulative cash growth five years prior and after the following crises: Australia (1989), Canada (1983), Denmark (1987), France (1994), Germany (1977), Greece (1991), Iceland (1985), and Italy (1990), and New Zealand (1987), United Kingdom (1974, 1991, 1995), and United States (1984). The Euro, 2008 Crisis line is the average cumulative assets growth five years prior and after the following 2008 crises: Austria, Belgium, Denmark, France, Greece, Hungary, Ireland, Italy, Latvia, Luxembourg, Portugal, Slovenia, Spain, Netherlands, and Sweden.

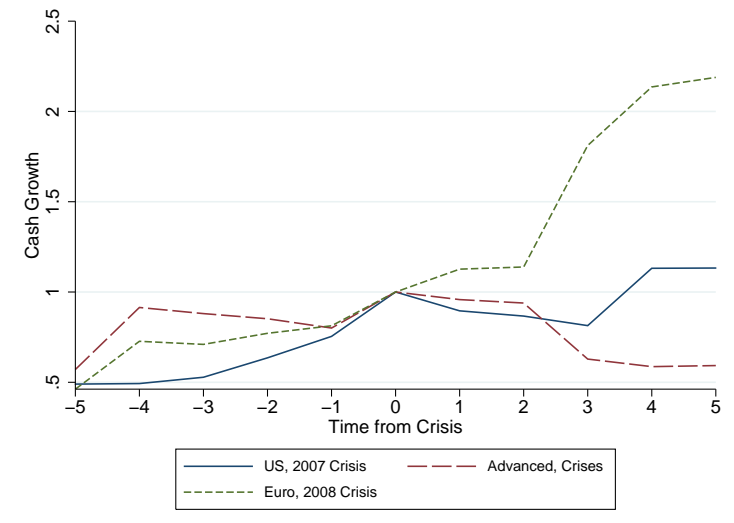

(a) US banks (All)

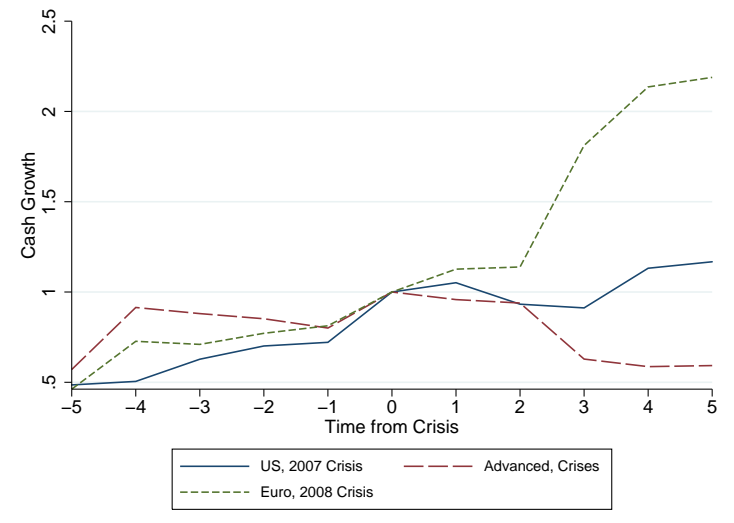

(b) US banks (Specific)

Figure 5 confirms the above findings for the case of the cash-to-assets ratio. 
Figure 5: Total cumulative cash/assets growth (five years prior and after the crisis). In figure (a) the U.S., 2007 Crisis line is the total cumulative cash/assets growth for U.S. banks five years prior and after the 2007 Crisis In figure (b) the U.S., 2007 Crisis line is the total cumulative cash/assets growth for specific U.S. banks (Bank of America, Citigroup, Goldman Sachs, JP Morgan, Morgan Stanley, and Wells Fargo) five years prior and after the 2007 Crisis. The Advanced, Crises line is the average cumulative cash/assets growth five years prior and after the following crises: Australia (1989), Canada (1983), Denmark (1987), France (1994), Germany (1977), Greece (1991), Iceland (1985), and Italy (1990), and New Zealand (1987), United Kingdom $(1974,1991,1995)$, and United States (1984). The Euro, 2008 Crisis line is the average cumulative assets growth five years prior and after the following 2008 crises: Austria, Belgium, Denmark, France, Greece, Hungary, Ireland, Italy, Latvia, Luxembourg, Portugal, Slovenia, Spain, Netherlands, and Sweden.

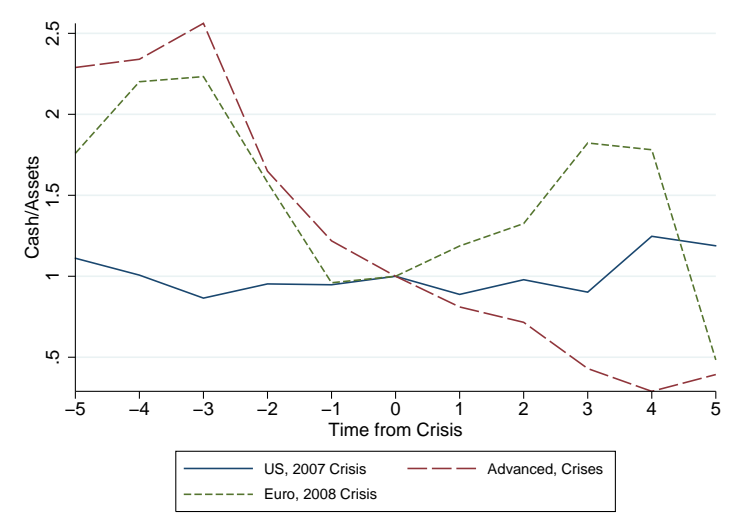

(a) US banks (All)

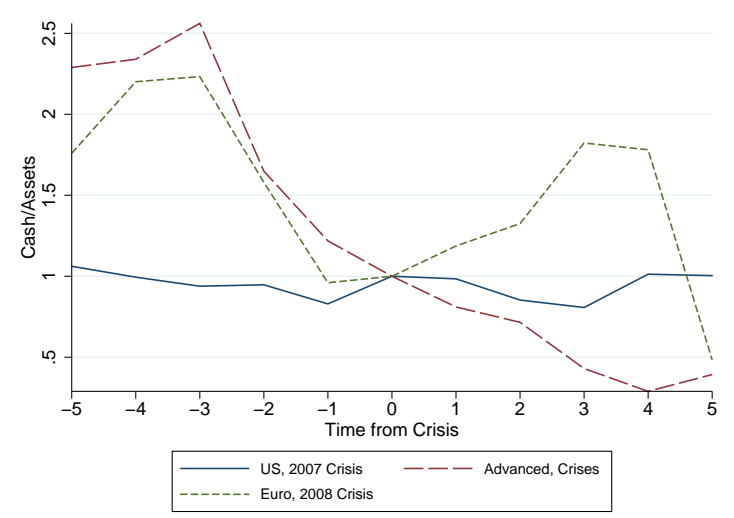

(b) US banks (Specific)

\subsection{The Dispersion of Bank Q-ratios}

We next examine the dispersion of bank Q-ratios. In theory, as capital is reallocated, efficiency would result in all firms having a Q of one. Capital should flow from firms with low Q's to firms with high Q's. For example, if there is a financial liberalization, giving nonfinancial firms equal access to credit, then the dispersion of Q for the nonfinancial firms should go down. Indeed, it does. See, e.g., Abiad et al. (2008) 9 However, in a financial crisis banks are not functioning well, and the dispersion of Q's for nonfinancial firms does not go down; see Chousakos et al. (2016). Post-crisis there are impediments to the reallocation of capital, because of the damage to the banking sector. What should we expect of the dispersion of banks' Q's during and after a crisis? If less efficient, low $\mathrm{Q}$, banks fail and investment flows to higher $\mathrm{Q}$ banks then dispersion should be reduced. But, if this does not happen for nonfinancial firms post-crisis, it is hard to understand how it could happen for banks.

Figure 6 below shows the average standard deviation of cross-sectional bank Q-ratios for five years prior to and five years after the financial crisis (normalized to one five years prior to the crises). It is striking that the average standard deviation is declining post-crisis, and especially so for the six former U.S. investment

\footnotetext{
${ }^{9}$ The dispersion of Q is often used as a measure of capital reallocation. For example, Eisfeldt and Rampini (2006) use the dispersion of $\mathrm{Q}$ for this purpose.
} 
banks. For U.S. commercial banks, the trend is upwards until the crisis and then downwards. The decline in the dispersion of bank Q's is paradoxical. It seems unlikely that the reason for the decline in the dispersion of $\mathrm{Q}$ is that capital is being reallocated in the banking sector at the very time when the banking sector is weak. We saw in Figures 1 and 2 that bank Q's are below one following the crisis, meaning that capital should be flowing out of this sector. Can this happen when banks are being required to hold more capital? Another possible explanation is that the raft of new regulations is essentially homogenizing banks at low Q's.

Figure 6: Average standard deviation of cross-sectional Q-ratios (five years prior and after the crisis, standardized to begin at 1 for all three categories). In figure (a) the U.S., 2007 Crisis line is the average standard deviation of cross-sectional Q-ratios for U.S. banks five years prior and after the 2007 Crisis In figure (b) the U.S., 2007 Crisis line is the average standard deviation of cross-sectional Q-ratios for specific U.S. banks (Bank of America, Citigroup, Goldman Sachs, JP Morgan, Morgan Stanley, and Wells Fargo) five years prior and after the 2007 Crisis. The Advanced, Crises line is the average standard deviation of cross-sectional Q-ratios five years prior and after the following crises: Australia (1989), Canada (1983), Denmark (1987), France (1994), Germany (1977), Greece (1991), Iceland (1985), and Italy (1990), and New Zealand (1987), United Kingdom (1974, 1991, 1995), and United States (1984). The Euro, 2008 Crisis line is the average standard deviation of cross-sectional Q-ratios five years prior and after the following 2008 crises: Austria, Belgium, Denmark, France, Greece, Hungary, Ireland, Italy, Latvia, Luxembourg, Portugal, Slovenia, Spain, Netherlands, and Sweden.

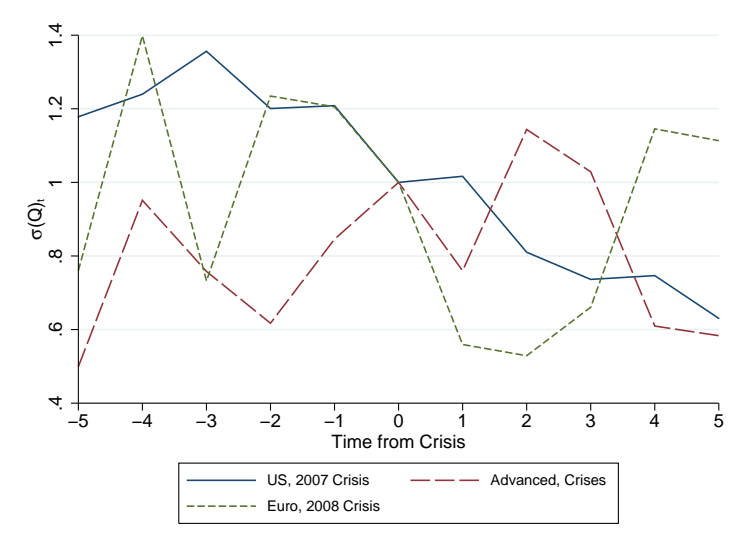

(a) US banks (All)

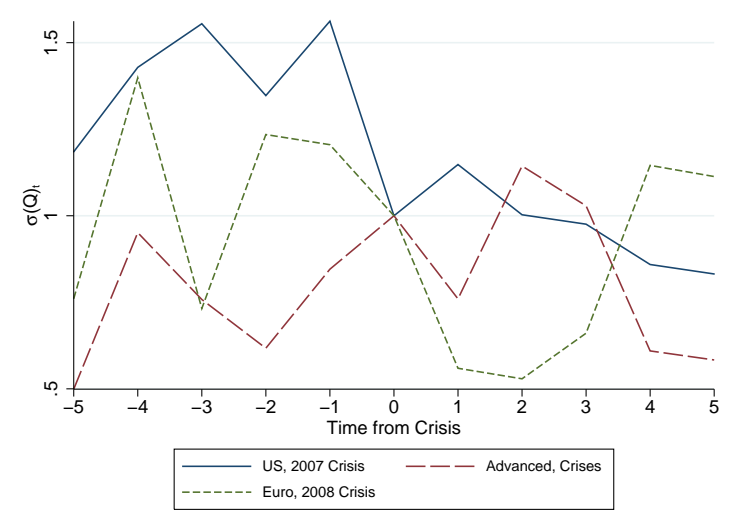

(b) US banks (Specific)

\section{Conclusion}

U.S. banks since the Financial Crisis of 2007-2008 and European banks following the Euro Crisis have been persistently unhealthy as measured by Tobin's Q. Of course, there can be many, nonmutually exclusive, reasons for this continuing ill health. However, the state of the macro-economy does not seem to explain low bank Q's. The zero lower bound of interest rates also does not seem to explain the low Q's. So, what does explain the low Q's? An important remaining possibility is whether post-crisis bank regulation has been repressive, so much so that it accounts for the low Q's. And, regulation could account for a decline in the 
dispersion of bank Q-ratios. If banks' business models are permanently damaged due to regulation, then their long-run survival is in question (at least in their current form). Post-crisis heightened survival risk is consistent with the results of Sarin and Summers (2016) who show that banks are riskier. New regulations may have made banks "safer" in that banks are less likely to be subject to bank runs. But, that may have come at a very high cost.

To be clear, we have not shown any direct evidence on whether or not the cumulative effects of new bank regulations are repressive or not. We have just summarized data. But, some recent trends also seem to suggest this. Lux and Greene (2015), for example, point out that in 2014 nonbanks accounted for over 40 percent of mortgage originations while in 2010 this number was 12 percent. And according to Nash and Beardsley (2015), peer-to-peer lending grew from $\$ 26$ million in 2009 to $\$ 1.7$ billion in 2014. They argue that: "Regulation will continue to shift activities from banks to nonbanks" (p. 1). Academic research is also emerging that is consistent with this view. Morris-Levenson et al. (2017) study cross-sectional heterogeneity in the regulatory exposure of different types of mortgage originators in the U.S. They find that less regulated banks and nonbank firms have a larger share of the mortgage origination market post-crisis. Is this the start of a new shadow banking system due to post-crisis constraining bank regulations? Not clear. But still, the question is very important and the evidence we have produced is (to us) striking and suggestive. 


\section{References}

Abiad, Abdul, Nienke Oomes, and Kenichi Ueda, "The quality effect: Does financial liberalization improve the allocation of capital?," Journal of Development Economics, 2008, 87 (2), 270-282.

Calomiris, Charles and Doron Nissim, "Crisis-Related Shifts in the Market Valuation of Banking Activities," Journal of Financial Intermediation, 2014, 23, 400-4350.

- and Joseph R. Mason, "Consequences of Bank Distress During the Great Depression," American Economic Review, 2003, 93 (3), 937-947.

Caprio, Gerard, Daniela Klingebiel, Luc Laeven, and Guillermo Noguera, "Appendix: Banking Crisis Database," in Patrick Honohan and Luc Laeven, eds., Systemic Financial Crises: Containment and Resolution, Cambridge: Cambridge University Press, 009 2005, pp. 307-340.

Carlson, Mark and Jonathan D. Rose, "Credit Availability and the Collapse of the Banking Sector in the 1930s," Journal of Money, Credit and Banking, 2015, 47 (7), 1239-1271.

Cerra, Valerie and Sweta Saxena, "Growth Dynamics: The Myth of Economic Recovery," American Economic Review, 2008, 98 (1), 439-57.

Chodorow-Reich, Gabriel, "The Employment Effects of Credit Market Disruptions Firm-level Evidence from the 2008-9 Financial Crisis," The Quarterly Journal of Economics, 2014, 129 (1), 1-59.

Chousakos, Kyriakos, Gary Gorton, and Guillermo Ordonez, "Aggregate Information Dynamics," Working Paper, Yale University 2016.

Chung, Kee H. and Stephen W. Pruitt, "A Simple Approximation of Tobin's q," Financial Management, 1994, $23(3)$.

Darmouni, Olivier, "Estimating Information Frictions in Sticky Relationships," Working Paper, Columbia University 2016.

Dell'ariccia, Giovanni, Enrica Detragiache, and Raghuram Rajan, "The real effect of banking crises," Journal of Financial Intermediation, 2008, 17 (1), 89-112.

Demsetz, Rebecca, Marc R. Saidenberg, and Philip E. Strahan, "Banks with something to lose: the disciplinary role of franchise value," Economic Policy Review, 1996, (Oct), 1-14.

Eisfeldt, Andrea and Adriano Rampini, "Capital reallocation and liquidity," Journal of Monetary Economics, 2006, 53 (3), 369-399. 
Frydman, Carola, Eric Hilt, and Lily Y. Zhou, "Economic Effects of Runs on Early "Shadow Banks": Trust Companies and the Impact of the Panic of 1907," Journal of Political Economy, 2015, 123 (4), 902 940.

Gibson, Michael S., "Can Bank Health Affect Investment? Evidence from Japan," Journal of Business, 1995, 68 (3), 281-308.

Gorton, Gary and Ping He, "Bank Credit Cycles," Review of Economic Studies, 2008, 75 (4), 1181-1214.

- and Richard Rosen, "Corporate Control, Portfolio Choice, and the Decline of Banking," Journal of Finance, 1995, 50 (5), 1377-1420.

Ivashina, Victoria and David Scharfstein, "Bank lending during the financial crisis of 2008," Journal of Financial Economics, 2010, 97 (3), 319-338.

Iyer, Rajkamal, Jose-Luis Peydro, Samuel da Rocha-Lopes, and Antoinette Schoar, "Interbank Liquidity Crunch and the Firm Credit Crunch: Evidence from the 2007-2009 Crisis," Review of Financial Studies, 2014, 27 (1), 347-372.

Kaminsky, Graciela and Carmen Reinhart, "The Twin Crises: The Causes of Banking and Balance-ofPayment Problems," American Economic Review, 1999, 89 (3), 473-500.

Keeley, Michael C., "Deposit Insurance, Risk, and Market Power in Banking," The American Economic Review, 1990, 80 (5), 1183-1200.

Lee, James and Filippo Mezzanotti, "Bank Distress and Manufacturing: Evidence from the Great Depression," Working Paper, Harvard University OpenScholar 2014.

Lux, Marshall and Robert Greene, "What's Behind the Non-Bank Mortgage Boom?," Working Paper, Harvard Kennedy School 2015.

Marcus, Alan, "Deregulation and Bank Financial policy," Journal of Banking and Finance, 1984, 8 (4), $557-565$.

Mladjan, Mrdjan, "Accelerating into the Abyss: Financial Dependence and the Great Depression," Working Paper, EBA Business School 2012.

Morris-Levenson, Josh, Robert Sarama, and Christoph Ungerer, "Does Tighter Bank Regulation Affect Mortgage Originations?," Working Paper, Board of Governors, Federal Reserve System 2017.

Nash, Ryan and Eric Beardsley, "The Future of Finance: The Rise of the New Shadow Bank," Goldman Sachs Equity Research, 2015. 
Reinhart, Carmen and Kenneth Rogoff, "Recovery from Financial Crises: Evidence from 100 Episodes," American Economic Review, 2014, 104 (5), 50-55.

Rosengren, Eric and Joe Peek, "Collateral Damage: Effects of the Japanese Bank Crisis on Real Activity in the United States," American Economic Review, 2000, 90 (1), 30-45.

Sarin, Natasha and Lawrence H. Summers, "Have big banks gotten safer?," Brookings Papers on Economic Activity, 2016, (Sep).

Slovin, Myron B, Marie E Sushka, and John A Polonchek, "The Value of Bank Durability: Borrowers as Bank Stakeholders," Journal of Finance, 1993, 48 (1), 247-66. 